\title{
PERBANDINGAN SIFAT GELATIN YANG BERASAL DARI KULIT IKAN PATIN (Pangasius hypophthalmus) DAN GELATIN YANG BERASAL DARI KULIT IKAN KOMERSIL
}

\author{
${ }^{1)}$ Ira Oktaviani RZ, Fitra Perdana, Azlaini Yus Nasution \\ 1) Analis Farmasi dan Makanan, FKIK Universitas Abdurrab \\ Jl. Riau Ujung No.73, Pekanbaru, Riau \\ email : ira.oktaviani@univrab.ac.id
}

\begin{abstract}
Gelatin is widely used in the food, pharmaceutical, and cosmetic industries. The demand for gelatin increases every year, gelatin derived from pigs and cows is the main source of gelatin in the market. Gelatin that is sourced from other animals such as from poultry and fish is only about $1 \%$.

Gelatin from fish becomes a better prospect to develop. Gelatin raw materials can be obtained from the skin, bones, and fish fins. Fish skin is a waste processing of fishery products, such as in the manufacture of meatballs, crackers, and so forth, which has no economic value and even harmful. "Patin" catfish is one of the most developed fish due to the high demand from both domestic and international market. Kampar Regency Riau Province is one of the centers of "patin"catfish development in Indonesia. Gelatin is valuable for the pharmaceutical and cosmetic industries because it is used in various formulations. This study aims to see the quality of gelatin obtained from catfish skin obtained by acidification process which will be continued utilization as additional material in cosmetic manufacture.

In this study, gelatin obtained from "patin" catfish skin extraction was evaluated organoleptically including odor, taste, and shape, moisture content, ash content, $\mathrm{pH}$, and protein contained therein, which results were compared with gelatin derived from commercial fish skins. In organoleptis, the resulting odor is dry powder, odorless, and tasteless, the average water content of commercial fish gelatin is $10.03 \%$ and of catatin gelatin is $9.92 \%$, the mean ash content obtained from commercial gelatin fish $2,1958 \%$ and "patin" catfish gelatin equal to $0,15 \%$, average protein content on gelatin of commercial fish equal to $85,68 \%$ and from "patin" catfish gelatin equal to $88,38 \%, \mathrm{pH}$ obtained in commercial fish gelatin 6.4 and from "patin"catfish gelatin of 5.7.
\end{abstract}

Keywords: gelatin," patin" catfih, fish skin

\begin{abstract}
ABSTRAK
Gelatin banyak digunakan dalam industri makanan, farmasi, dan kosmetik. Permintaan akan gelatin meningkat setiap tahun, gelatin yang berasal dari babi dan sapi merupakan sumber utama gelatin yang ada di pasaran. Gelatin yang bersumber dari hewan lain seperti dari unggas dan ikan hanya sekitar 1\% .

Gelatin dari ikan menjadi prospek yang lebih bagus untuk dikembangkan. Bahan baku gelatin dapat diperoleh dari kulit, tulang, maupun sirip ikan. Kulit ikan merupakan limbah pengolahan hasil perikanan, seperti pada industri pembuatan bakso, kerupuk, dan sebagainya, yang tidak mempunyai nilai ekonomis bahkan dapat merugikan. Ikan patin merupakan salah satu ikan yang banyak dikembangkan karena tingginya permintaan baik dari pasar domestik maupun internasional. Kabupaten Kampar Provinsi Riau merupakan salah satu sentra pengembangan ikan patin di Indonesia. Gelatin bernilai bagi industri farmasi dan kosmetik karena digunakan dalam berbagai formulasi.

Penelitian ini bertujuan untuk melihat kualitas gelatin yang diperoleh dari kulit ikan patin yang diperoleh melalui proses pengasaman yang nantinya akan dilanjutkan pemanfaatannya sebagai bahan tambahan di dalam pembuatan kosmetik. Pada penilitian ini, gelatin yang didapat dari ekstraksi kulit ikan patin dievaluasi secara organoleptis meliputi bau, rasa, dan bentuk, kadar air, kadar abu, pH, dan protein yang terkandung di dalamnya, dimana hasilnya dibandingkan dengan gelatin yang berasal dari kulit ikan komersil. Pada organoleptis, bau yang dihasilkan berupa serbuk kering, tidak berbau, dan tidak berasa, kadar air rata-rata
\end{abstract}


dari gelatin ikan komersil sebesar 10,03\% dan dari gelatin ikan patin sebesar 9,92\%, kadar abu rata-rata yang diperoleh dari gelatin iakn komersil sebesar 2,1958\% dan gelatin ikan patin sebesar 0,15\%, kadar protein rata-rata pada gelatin ikan komersil sebesar $85,68 \%$ dan dari gelatin ikan patin sebesar 88,38\%, pH yang diperoleh pada gelatin ikan komersil 6,4 dan dari gelatin ikan patin sebesar 5,7.

Kata Kunci: gelatin, patin, kulit ikan

\section{Pendahuluan}

Gelatin banyak digunakan dalam industri makanan, farmasi, dan kosmetik. Pada industri makanan, gelatin digunakan sebagai bahan penstabil, pembentuk gel, dan edible coating. Pada industri farmasi gelatin digunakan sebagai bahan untuk pembuatan kapsul, penyalut tablet, penstabil, pengikat, dan pengemulsi. Pada industri kosmetik, gelatin digunakan sebagai bahan pembuatan krim (Schreiber \& Gareis, 2007). Permintaan akan gelatin meningkat setiap tahun, gelatin yang berasal dari babi dan sapi merupakan sumber utama gelatin yang ada di pasaran (Gómez-Guillén et al., 2009). Gelatin yang bersumber dari hewan lain seperti dari unggas dan ikan hanya sekitar 1\% (Duconseille, Astruc, Quintana, Meersman, \& Sante-Lhoutellier, 2015). Gelatin dari ikan menjadi prospek yang lebih bagus untuk dikembangkan. Bahan baku gelatin dapat diperoleh dari kulit, tulang, maupun sirip ikan. Kulit ikan merupakan limbah pengolahan hasil perikanan, seperti pada industri fillet, yang tidak mempunyai nilai ekonomis bahkan dapat merugikan (Badii \& Howell, 2006).

Kabupaten Kampar Provinsi Riau merupakan salah satu sentra pengembangan ikan patin di Indonesia. Ikan patin yang diolah menjadi fillet mempunyai nilai ekonomis yang lebih tinggi (Indonesia, 2013). Pengolahan ini menghasilkan limbah berupa kulit dan tulang ikan. Limbah tersebut menimbulkan masalah bagi lingkungan karena pemanfaatan limbah belum maksimal (Agustin, 2013). Kulit ikan ini dapat menjadi sumber bahan baku pembuatan gelatin, sehingga mempunyai nilai ekonomis dan sekaligus dapat mengatasi masalah limbah yang ditimbulkan terhadap lingkungan. Penelitian tentang ekstraksi gelatin dari ikan telah banyak dilakukan, seperti pada ikan salmon, hiu, nila, lele, dan lain-lain (Karim \& Bhat, 2009) ;(Liu, Li, \& Guo, 2008). (Mahmoodani, Ardekani, Fern, Yusop, \& Babji, 2014) telah melakukan penelitian tentang ekstraksi gelatin dari kulit ikan patin (Pangasius sutchi). Jenis ikan patin yang dikembangkan di Indonesia adalah Pangasius hypophthalmus (Indonesia, 2013), sehingga perlu dilakukan penelitian tentang gelatin dari kulit ikan patin ini. Kulit ikan sebagai bahan baku pembuatan gelatin biasanya dibekukan dalam penyimpanan dan pengangkutannya. Sekarang ini telah banyak beredar di pasaran gelatin yang berasal dari ikan komersil, namun tidak diketahui berasal dari ikan jenis apa. Penelitian ini dimaksudkan untuk melihat perbandingan sifat gelatin yang diekstraksi dari kulit ikan patin (Pangasius hypophthalmus) dengan sifat gelatin ikan komersil yang diperoleh di pasaran. Penelitian ini bertujuan agar mengetahui sifat gelatin hasil ekstraksi dari ikan patin yang dibandingkan dengan gelatin ikan komersil sehingga dapat dijadikan sebagai bahan tambahan dalam pembuatan kosmetik.

\section{Tinjauan Pustaka \\ 2.1 Gelatin}

Gelatin terbuat dari hidrolisis parsial kolagen. Gelatin terdiri dari 85 sampai $92 \%$ protein, sisanya adalah garam mineral dan air yang masih tertinggal setelah pengeringan. Kolagen adalah jenis protein yang banyak terdapat pada hewan dan manusia. Struktur kolagen berbentuk linier dan seperti serat (Schreiber \& Gareis, 2007). Gelatin yang terdapat di pasaran umumnya dibuat dari dari hidrolisis tulang sapi, kulit sapi, dan kulit babi (GMIA, 2012).

Gelatin membentuk larutan koloid dengan air sehingga disebut hidrokoloid. Sifat hidrokoloid gelatin sejenis dengan pektin, karagenan, gom arab, dan lain-lain. Hidrokoloid banyak digunakan di industri makanan karena nilai gizinya dan bersifat multi fungsi. Walaupun pemakaian satu jenis hidrokoloid tidak memenuhi sifat yang diinginkan, tetapi gelatin mempunyai fungsi yang lebih beragam dibandingkan dengan hidrokoloid lainnya.

Penggunaan gelatin telah lama dikenal dalam berbagai bidang. Pada industri farmasi, gelatin digunakan sebagai bahan pembuat kapsul keras dan lunak, bahan penyalut tablet, penstabil, pengikat, dan 
pengemulsi. Di industri makanan, digunakan sebagai bahan penstabil pada pembuatan susu, coklat, marshmallow, permen, jelly, dan dewasa ini berkembang sebagai bahan pembungkus yang dapat dimakan (edible coating). Begitu juga pada industri kosmetik, gelatin digunakan sebagai bahan penstabil, pembentuk gel, pengemulsi, dan pengental. Selain itu, gelatin juga digunakan pada bidang kedokteran, teknik, dan fotografi (Schreiber \& Gareis, 2007).

\subsection{Sifat Fisika Kimia Gelatin}

Sifat fisika kimia gelatin pada dasarnya ditentukan oleh asam amino penyusun molekul gelatin. Gelatin berupa lembaran, kepingan atau potongan atau serbuk kasar sampai halus, kuning lemah atau coklat terang, warna bervariasi tergantung ukuran partikel. Sifat kelarutan gelatin adalah tidak larut dalam air dingin, mengembang dan lunak bila dicelup dalam air, menyerap air secara bertahap sebanyak 5 sampai 10 kali beratnya. Larut dalam air panas, dalam asam asetat $6 \mathrm{~N}$ dan dalam campuran panas gliserin dan air, tidak larut dalam etanol, dalam kloroform, dalam eter, dalam minyak lemak dan dalam minyak menguap. Pada larutan asam atau basa kuat, gelatin akan mengalami presipitasi (RI, 1995). Gelatin larut dalam air hangat dan apabila didinginkan di bawah suhu $30^{\circ} \mathrm{C}$, larutan koloid akan membentuk gel dengan sifat tiksotropik dan reversibel menjadi cair kembali apabila dipanaskan.

Gelatin merupakan sistem koloidal padat (protein) dalam cairan (air) sehingga pada suhu dan kadar air yang tinggi gelatin mempunyai kemampuan cairan, yaitu disebut fase sol atau hidrosol, sebaliknya pada suhu dan kadar air yang rendah gelatin meempunyai kemampuan yang lebih kasar atau lebih pekat strukturnya, yaitu disebut fase gel (Schreiber \& Gareis, 2007).

Gelatin berasal dari kolagen, yang merupakan suatu protein. Seperti umumnya protein, kolagen yang mempunyai struktur primer, sekunder dan tersier. Bentuk protein kolagen adalah linier menyerupai serat. Susunan asam amino pada gelatin hampir mirip dengan kolagen, dimana $2 / 3$ asam amino penyusunnya didominasi oleh glisin. Sementara, 1/3 asam amino yang tersisa disusun oleh prolin dan hidroksiprolin. Pada gelatin, asam amino saling terikat melalui ikatan peptida. Namun, gelatin tidak dapat digolongkan sebagai proein lengkap karena tidak adanya triptofan dan histidin (Grobben, Steele, Somerville, \& Taylor, 2004).

Asam glutamat dan asam aspartat yang menyusun kolagen lebih banyak berada dalam bentuk amidanya (sekitar 35\%) yaitu sebagai glutamin dan asparagin. Pada gelatin tipe B (basa), asparagin dan glutamin hampir semua diubah menjadi asam aspartat dan asam glutamat. Sementara itu komposisi asam amino kolagen dan gelatin tipe A (asam) sangat berbeda. Hal ini dapat dijelaskan dari perbedaan titik isoeletrik (IEP) pada kedua jenis gelatin. Titik isoelektrik adalah nilai $\mathrm{pH}$ saat molekul gelatin bermuatan netral. Titik isoelektrik gelatin tipe A pada pH 8-9, dan tipe B pada pH 4,8-5,5 (Schreiber \& Gareis, 2007).

\subsection{Pembuatan Gelatin}

Hidrolisis kolagen menjadi gelatin dapat terjadi secara kimia, yaitu dengan perendaman dalam waktu tertentu dengan suatu asam ataupun basa. Selain dengan cara kimia, hidrolisis juga dapat terjadi secara enzimatis dengan bantuan enzim kolagenase yang spesifik.

Pada pembuatan gelatin, perlakuan bahan baku berupa kolagen hewan dengan asam encer atau dengan basa menyebabkan pemotongan ikatan silang protein, strukturnya menjadi putus dan potongan-potongan tersebut larut dalam air. Potongan-potongan rantai protein yang larut air ini disebut gelatin. Kualitas gelatin yang dihasilkan bergantung pada konsentrasi asam atau basa yang digunakan, temperatur dan lamanya waktu perendaman (GMIA, 2012).

Pada prinsipnya proses pembuatan gelatin dapat dibagi menjadi dua jenis yaitu proses asam dan proses basa. Berdasarkan hal tersebut gelatin digolongkan ke dalam dua tipe, yaitu gelatin tipe A dan tipe B.

1. Gelatin tipe A (Acid)

Gelatin tipe A diperoleh melalui perendaman bahan baku menggunakan asam encer. Metode ini cocok untuk bahan baku kolagen yang diperoleh dari hewan yang masih muda atau dari bahan kulit. Ikatan silang pada kolagen masih lemah sehingga untuk memutuskan ikatan tersebut cukup dengan larutan asam encer. Perendaman dapat dilakukan menggunakan asam klorida 2-6\% selama 24-72 jam pada suhu kamar (GMIA, 2012). 
2. Gelatin tipe B (Base)

Gelatin tipe B diperoleh dengan proses pengkondisian menggunakan larutan basa. Bahan bakunya adalah dari tulang atau kolagen hewan yang sudah agak tua. Tergantung pada konsentrasi alkali dan temperatur yang digunakan, proses perendaman bisa beberapa hari sampai berbulan-bulan. Jika menggunakan larutan $\mathrm{NaOH} 1 \%$ pada temperatur $20^{\circ} \mathrm{C}$, maka proses pengkondisian bisa beberapa hari. Namun jika menggunakan larutan kapur bisa lebih dari 1 bulan. Walaupun proses ini sangat lama, tetapi dihasilkan gelatin dengan kemurnian tinggi.

\subsection{Gelatin dari Ikan}

Gelatin ikan biasanya diekstraksi dari kulit ikan dalam keadaan asam atau basa. Kulit ikan dapat diperoleh dari produsen fillet ikan. Kulit ikan dibersihkan dengan baik agar lemak yang terdapat pada kulit ikan hilang. Kulit ikan dibekukan dan dibawa ke pabrik gelatin. Di sana akan dicairkan, dicuci, dan ditambahkan asam organik atau mineral selama 24 jam. Kadang dilakukan perlakuan tahap awal dengan menambahkan kalsium karbonat terlebih dahulu yang berfungsi untuk mengikat lemak. Gelatin yang diperoleh dari ikan di Atlantik Utara mengandung prolin dan hidroksiprolin yang lebih sedikit. Hal ini menyebabkan kekuatan gel gelatin ini berkurang, walaupun bobot molekulnya tinggi (Schreiber \& Gareis, 2007).

Sifat dari gelatin yaitu dapat membentuk lapisan film dengan baik dan juga bersifat emulgator. Gelatin dari ikan menunjukkan sifat gelling yang baik, mempunyai kemiripan dengan gelatin yang umumnya dari sapi atau babi, dan sering digunakan dalam industri makanan dan farmasi. Perlu diketahui, bahwa sifat gelatin yang dihasilkan bergantung pada jenis ikan, dan proses ekstraksi gelatin tersebut. Seperti gelatin yang dibuat dari ikan tuna mempunyai sifat yang berbeda dengan ikan nila. Sekarang ini, gelatin ikan lebih mahal dibandingkan gelatin yang sudah ada di pasaran, hal ini karena biaya transportasi dan konsentrasi kolagen pada kulit ikan rendah, dan masih berpotensi menimbulkan alergi.

\subsection{Kualitas Gelatin}

Kualitas gelatin sangat dipengaruhi oleh sifat fisika dan kimianya, selain itu sifat fungsional gelatin juga merupakan parameter yang penting. Parameter-parameter fungsional ini adalah:

1. Kekuatan gel (nilai Bloom)

Sifat utama gelatin yang digunakan di industri adalah mampu membentuk gel (gelling agent). Kekuatan gel adalah parameter utama dan sangat berpengaruh terhadap harga gelatin yang dipasarkan. Kekuatan gel diukur dengan alat yang disebut alat uji Bloom. Sebelum diukur, gelatin dikondisikan pada suhu $10^{\circ} \mathrm{C}$ selama $17 \mathrm{jam}$ dengan konsentrasi $6,67 \% \mathrm{~b} / \mathrm{v}$. Suatu kekuatan yang digunakan untuk menekan permukaan suatu massa gel disebut sebagai gram Bloom atau disingkat Bloom. Nilai Bloom gelatin berkisar antara 50-300 Bloom. nilai tersebut dibagi ke dalam 3 klasifikasi yaitu bloom rendah untuk nilai 50-100 Bloom, bloom sedang untuk nilai 100-200 Bloom dan bloom tinggi untuk nilai 200-300 Bloom (Ahmad \& Benjakul, 2011).

2. Viskositas

Gelatin dengan viskositas yang tinggi diperlukan untuk menghasilkan kestabilan produk makanan, sediaan farmasi, dan industri fotografi. Pengukuran viskositas dilakukan terhadap larutan gelatin dengan konsentrasi $6,67 \% \mathrm{~b} / \mathrm{v}$ yang dilarutkan pada suhu $60^{\circ} \mathrm{C}$, lalu dibiarkan hingga suhu $30^{\circ} \mathrm{C}$.

3. $\mathrm{pH}$

$\mathrm{pH}$ gelatin berpengaruh terhadap pembentukan busa pada proses pembentukan gel dan interaksinya dengan komponen lain pada proses formulasi. $\mathrm{pH}$ larutan gelatin diukur menggunakan $\mathrm{pH}$ meter.

4. Kadar air

Kadar air gelatin yang dipersyaratkan adalah $9-11 \%$ pada kondisi normal. Kadar air ini dipengaruhi oleh udara di sekelilingnya, gelatin dapat mengabsorbsi atau melepaskan air yang dikandungnya. Jika kandungan air lebih dari 16\%, maka gelatin akan mudah ditumbuhi mikroba dan resiko terbentuknya gumpalan semakin besar (SNI 01-3735-1995). Untuk mengukur kadar air dapat dilakukan pengeringan pada suhu $105 \pm 2^{\circ} \mathrm{C}$ selama $16-18 \mathrm{jam}$. 


\section{Metode Penelitian}

\subsection{Jenis Penelitian}

Jenis penelitian yang digunakan adalah penelitian true eksperimental laboratories.

\subsection{Tempat dan Waktu Penelitian}

Penelitian dilakukan di Laboratorium Makanan Fakultas Kedokteran dan Ilmu Kesehatan Universitas Abdurrab, Laboratorium Instrumen Universitas Riau, pada bulan April sampai Desember 2017

\subsection{Bahan dan Alat}

Bahan yang digunakan pada penelitian ini adalah kulit ikan patin segar (Pangasius hypophthalmus), akuades, natrium hidroksida, asam asetat, gelatin ikan (Sigma Aldrich), selenium, asam sulfat pekat.

Alat yang digunakan adalah pisau, refrigerator, $\mathrm{pH}$ meter, penangas air, batang pengaduk, oven, erlenmeyer, cawan penguap, botol kaca bertutup, desikator, krus porselen, tanur, timbangan analitik, stirer, viskometer Brookfield, Kjeldahl apparatus.

\subsection{Cara Kerja}

\subsubsection{Pengambilan dan perlakuan sampel}

Ikan patin segar dibeli dari peternak ikan patin kampung Patin, kabupaten Kampar, Riau. Kulit ikan dipisahkan dari dagingnya menggunakan pisau dan dibersihkan dari sisa daging dan dicuci sampai bersih. Kulit ikan patin segar langsung diekstraksi, sementara itu sebagian kulit dibungkus dengan plastik .

\subsubsection{Ekstraksi gelatin dari kulit ikan patin}

\subsubsection{Persiapan sampel}

Kulit ikan direndam dalam air dingin dan diaduk menggunakan stirer untuk menghilangkan lemak. Kulit ikan ini dicuci sampai bersih, kemudian dipotong-potong hingga berukuran $2 \times 2 \mathrm{~cm}$ dan dijadikan sebagai bahan baku pembuatan gelatin.

\subsubsection{Proses ekstraksi}

Bahan baku kulit ikan ditimbang sebanyak 160g, lalu ditambahkan asam sulfat pH 3 (1:6). pH larutan dijaga tetap 3 dengan cara menambah asam sulfat. Hidrolisis ini dilakukan selama $12 \mathrm{jam}$. Setelah itu kulit ikan dicuci sampai $\mathrm{pH}$ netral. Setelah itu diekstraksi dengan aquades pada suhu $60^{\circ} \mathrm{C}$ selama $10 \mathrm{jam}$. Disaring tiga kali dengan kain kasa, lalu dituang ke dalam wadah yang sesuai dan dikeringkan menggunakan oven pada suhu $55^{\circ} \mathrm{C}$ (Muyonga, Cole, \& Duodu, 2004).

\subsubsection{Evaluasi terhadap gelatin hasil ekstraksi}

\section{A. Pengamatan organoleptis meliputi warna, bau, dan rasa larutan}

Pengamatan organoleptis gelatin dilakukan berdasarkan Standar Nasional Indonesia (SNI) 01-337351995. Gelatin hasil ekstraksi dari kulit ikan diamati warna, bentuk padatannya dan warna larutannya. Sebanyak $5 \mathrm{~g}$ gelatin dilarutkan dengan $100 \mathrm{ml}$ akuades suhu $60^{\circ} \mathrm{C}$. Larutan dibiarkan hingga suhu mencapai $32^{\circ} \mathrm{C}$ dan pada keadaan ini larutan memberikan rasa yang normal (hampir tidak berasa). Setelah itu, dibiarkan selama 48 jam dalam cawan petri pada suhu $27^{\circ} \mathrm{C}$ tidak menghasilkan bau yang tidak enak.

\section{B. Penetapan kadar air}

Penentuan kadar air dilakukan berdasarkan metode AOAC 1995. Wadah kaaca bertutup dikeringkan dalam oven suhu $100^{\circ} \mathrm{C}$, didinginkan, dan ditimbang sampai bobot konstan. Sebanyak $1 \mathrm{~g}$ serbuk gelatin diletakkan ke dalam wadah tersebut dan dimasukkan ke dalam oven suhu $100^{\circ} \mathrm{C}$ dalam keadaan terbuka. Wadah dan gelatin tadi didinginkan dalam desikator, lalu ditimbang hingga diperoleh bobt konstan. Persen penurunan bobot dihitung sebagai \% kadar air. 


\section{Pengukuran pH}

pH gelatin diukur menurut metode British Standard Institution (BSI), 1975. Sebanyak 1 gram gelatin dilarutkan dalam akuades suhu $45^{\circ} \mathrm{C}$ dan dicukupkan volumenya sampai $100 \mathrm{ml}$. Larutan dibiarkan mencapai suhu kamar, dan diukur $\mathrm{pH}$ larutan tersebut menggunakan $\mathrm{pH}$ meter.

\section{Penetapan kadar abu}

Kadar abu ditetapkan sesuai dengan metode AOAC 1995. Sebanyak $1 \mathrm{~g}$ serbuk gelatin dimasukkan pada cawan porselen yang telah ditimbang sampai bobot tetap sebelumnya. Setelah itu dipijarkan menggunakan tanur pada suhu $50^{\circ} \mathrm{C}$ hingga pengabuan sempurna. Selanjutnya wadah dan isinya didinginkan dalam desikator, ditimbang hingga diperoleh bobot tetap. Kadar abu dihitung dari pengurangan bobot yang didapat.

\section{Hasil Percobaan}

Hasil evaluasi gelatin dari ekstraksi kulit ikan patin dan ikan komersil dapat dilihat pada tabel di bawah ini:

Tabel 1 Perbandingan gelatin ekstraksi ikan patin dan ikan komersil

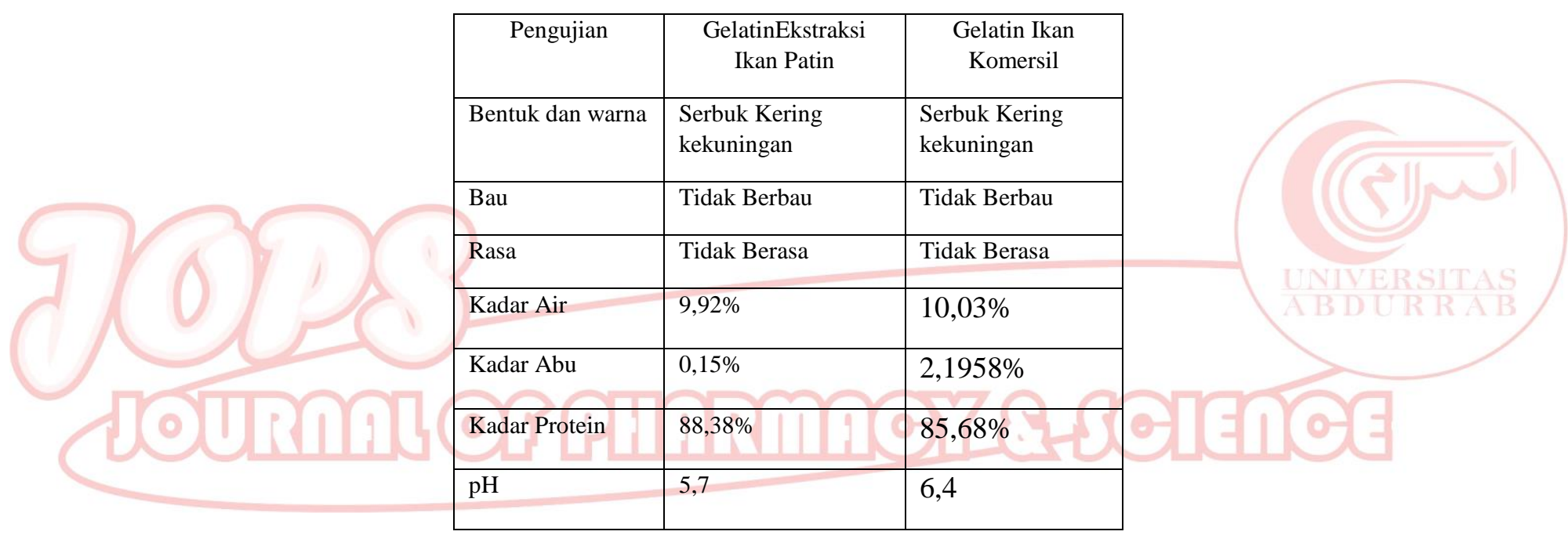

Proses pembuatan gelatin dilakukan menggunakan metode hidrolisis asam. Setelah dilakukan beberapa kali percobaan dengan menggunakan metode basa dan asam, maka dengan metode asam hasil yang didapatkan lebih cepat dan menyerupai gelatin produk ikan komersil. Proses penyiapan gelatin diawali dengan penyiapan bahan baku kulit ikan patin, dimana kulit ini diperoleh dari kampung Patin, kabupaten Kampar, Riau. Tahap awal adalah proses pembersihan kulit ikan yang diperoleh dengan air mengalir guna menghilangkan sisa-sisa lemak yang menempel pada kulit ikan.

Gelatin merupakan suatu biopolimer yang bersumber dari kolagen. Kolagen yang terdapat pada jaringan penghubung sulit untuk larut dalam air, bahkan air panas sekalipun. Hal ini disebabkan karena kuatnya ikatan silang ganda tiga yang merupakan rantai penyusun kolagen tersebut. Karena itu perlu dilakukan hidrolisis. Prinsip hidrolisis adalah memutuskan ikatan ganda tiga pada kolagen, namun rantai proteinnya tidak terpotong sehingga pemutusannya disebut dengan hidrolisis parsial (Karim \& Bhat, 2009). Ekstraksi gelatin dari kulit iakn patin dilakukan dengan metode hidrolisis asam. Digunakan metode ini karena hidrolisis asam cocok untuk bahan baku yang berasal dari kulit yang tidak terlalu tua. Hidrolisis asam juga mencegah terjadinya reaksi saponifikasi yang mungkin terjadi karena adanya sisa lemak pada kulit (Schreiber \& Gareis, 2007).

Dari hasil pengamatan organoleptis berupa warna, bau, dan rasa yang diperoleh dari ikan patin tidak jauh berbeda dari gelatin ikan komersil. Ini juga sesuai dengan persyaratan SNI 01-3735-1995 bahwa gelatin harus tidak berwarna sampai berwarna kekuningan. Gelatin yang diperoleh berwarna kekuningan, 
sebelum dihaluskan berupa lembaran tipis dan transparan. Untuk bau dan rasa kedua gelatin dilarutkan di dalam akuades, gelatin bersifat jernih, berwarna kekuningan dan tidak tercium bau kaldu.

Kadar air merupakan salah satu uji yang diperlukan di dalam parameter penentuan sifat gelatin. Gelatin yang kering bersifat stabil di udara. Jika dalam bentuk larutan lembab, gelatin mudah terurai oleh mikroorganisme. Kadar air gelatin yang dipersyaratkan adalah di bawah 16\% (Reynolds, 1982). Perhitungan kadar air gelatin ikan patin lebih baik dari pada ikan komersil dimana kadar air ikan patin sebesar $9,92 \%$ dan ikan komersil sebesar 10,03\%.

Kadar abu merupakan salah satu persyaratan yang harus dipenuhi oleh gelatin. Rendahnya kadar abu menunjukkan kualitas gelatin yang baik (Balti et al., 2011). Persyaratan kadar abu gelatin adalah tidak lebih dari $2 \%$ (Rogers, 2009) atau 2,5\%. Besar kecilnya kadar abu ditentukan oleh proses pencucian. Pada penelitian ini kadar abu gelatin ekstraksi kulit ikan patin jauh lebih rendah daripada gelatin ikan komersil. Gelatin kulit ikan patin sebesar 0,15\% sedangkan gelatin ikan komersil sebesar 2,1958\%.

Kandungan utama gelatin adalah protein. Tingginya kadar protein menunjukkan kualitas gelatin yang baik. Kadar protein gelatin kulit ikan patin sebesar $88,38 \%$, sedangkan kadar protein gelatin ikan komersil sebesar $85,68 \%$. Reaksi hidrolisis dan proses ekstraksi yang dilakukan mampu menghasilkan gelatin dengan kadar protein yang tinggi.

pH gelatin yang memenuhi persyaratan yaitu pH 3,8-5,5 (GMIA, 2012). pH memberikan pengaruh yang besar terhadap sifat gelatin sebagai bahan eksipien. $\mathrm{pH}$ sekitar 5 memberiakn efek ideal terhadap kekuatan gel yang dihasilkan (Shyni et al., 2014). Dari kedua gelatin, nilai pH gelatin ekstraksi ikan patin mendekati oH yang dipersyaratkan yaitu sebesar 5,7 sedangkan pH gelatin iakn komersil sebesar 6,4.

\section{Kesimpulan}

Adapun kesimpulan dari penelitian yang dilakukan anatara lain:

1. Gelatin hasil ekstraksi ikan patin memeiliki sifat organoleptis yang sama dengan gelatin ikan komersil.

2. Kadar air gelatin ekstraksi ikan patin sebesar 9,92\% lebih rendah dibandingkan dengan gelatin ikan komersil, dan kadar air yang diperoleh memenuhi persyaratan yang telah dipersyaratkan yaitu dibawah $16 \%$.

3. Kadar abu gelatin hasil ekstraksi ikan patin sebesar $0,15 \%$ sedangkan kadar abu gelatin ikan komersil sebesar 2, 1958\%, dimana kadar abu ini sesuai dengan yang dipersyaratkan yaitu tidak lebih dari $2 \%$.

4. Kadar protein gelatin hasil ekstraksi ikan patin lebih besar dibandingkan kadar protein gelatin ikan komersil.

5. $\mathrm{pH}$ gelatin ekstraksi ikan patin dan gelatin yang berasal dari ikan komersil belum memenuhi syarat yang ditentukan yaitu antara $3,8-5,5$.

\section{REFERENSI}

Agustin, A. T. (2013). Gelatin Ikan: Sumber, Komposisi Kimia dan Potensi Pemanfaatannya. Jurnal Media Teknologi Hasil Perikanan, 1(2).

Ahmad, M., \& Benjakul, S. (2011). Characteristics of gelatin from the skin of unicorn leatherjacket (Aluterus monoceros) as influenced by acid pretreatment and extraction time. Food Hydrocolloids, 25(3), 381-388.

Badii, F., \& Howell, N. K. (2006). Fish gelatin: structure, gelling properties and interaction with egg albumen proteins. Food Hydrocolloids, 20(5), 630-640.

Balti, R., Jridi, M., Sila, A., Souissi, N., Nedjar-Arroume, N., Guillochon, D., \& Nasri, M. (2011). Extraction and functional properties of gelatin from the skin of cuttlefish (Sepia officinalis) using smooth hound crude acid protease-aided process. Food Hydrocolloids, 25(5), 943-950.

Duconseille, A., Astruc, T., Quintana, N., Meersman, F., \& Sante-Lhoutellier, V. (2015). Gelatin structure and composition linked to hard capsule dissolution: a review. Food Hydrocolloids, 43, 360-376.

GMIA, G. H. (2012). Gelatin Manufacturers Institute of America. New York.

Gómez-Guillén, M. C., Pérez-Mateos, M., Gómez-Estaca, J., López-Caballero, E., Giménez, B., \& Montero, P. (2009). Fish gelatin: a renewable material for developing active biodegradable films. Trends in Food Science \& Technology, 20(1), 3-16.

Grobben, A. H., Steele, P. J., Somerville, R. A., \& Taylor, D. M. (2004). Inactivation of the bovine-spongiform-encephalopathy (BSE) agent by the acid and alkaline processes used in the 
manufacture of bone gelatine. Biotechnology and Applied Biochemistry, 39(3), 329-338.

Indonesia, K. P. R. (2013). Statistik Perdagangan Luar Negeri Indonesia. Jakarta: Direktorat Jenderal Pengembangan Ekspor Nasional.

Karim, A. A., \& Bhat, R. (2009). Fish gelatin: properties, challenges, and prospects as an alternative to mammalian gelatins. Food Hydrocolloids, 23(3), 563-576.

Liu, H., Li, D., \& Guo, S. (2008). Rheological properties of channel catfish (Ictalurus punctaus) gelatine from fish skins preserved by different methods. LWT-Food Science and Technology, 41(8), 1425-1430.

Mahmoodani, F., Ardekani, V. S., Fern, S. S., Yusop, S. M., \& Babji, A. S. (2014). Optimization of extraction and physicochemical properties of gelatin from pangasius catfish (Pangasius sutchi) skin. Sains Malaysiana, 43(7), 995-1002.

Muyonga, J. H., Cole, C. G. B., \& Duodu, K. G. (2004). Fourier transform infrared (FTIR) spectroscopic study of acid soluble collagen and gelatin from skins and bones of young and adult Nile perch (Lates niloticus). Food Chemistry, 86(3), 325-332.

Reynolds, J. E. F. (1982). Martindale: the extra pharmacopoeia. London, UK; The Pharmaceutical Press.

RI, D. P. O. M. D. (1995). Farmakope Indonesia. Ed. IV, Departemen Kesehatan RI, Jakarta.

Rogers, T. L. (2009). en "Handbook of pharmaceutical excipients", ed. por RC Rowe, 32. PJ Sheskey y ME Quinn. Pharmaceutical Press and American Pharmacists Association, London.

Schreiber, R., \& Gareis, H. (2007). Gelatine handbook. Weinhem: Wiley-VCH GmbH and Co, 347.

Shyni, K., Hema, G. S., Ninan, G., Mathew, S., Joshy, C. G., \& Lakshmanan, P. T. (2014). Isolation and characterization of gelatin from the skins of skipjack tuna (Katsuwonus pelamis), dog shark (Scoliodon sorrakowah), and rohu (Labeo rohita). Food Hydrocolloids, 39, 68-76.

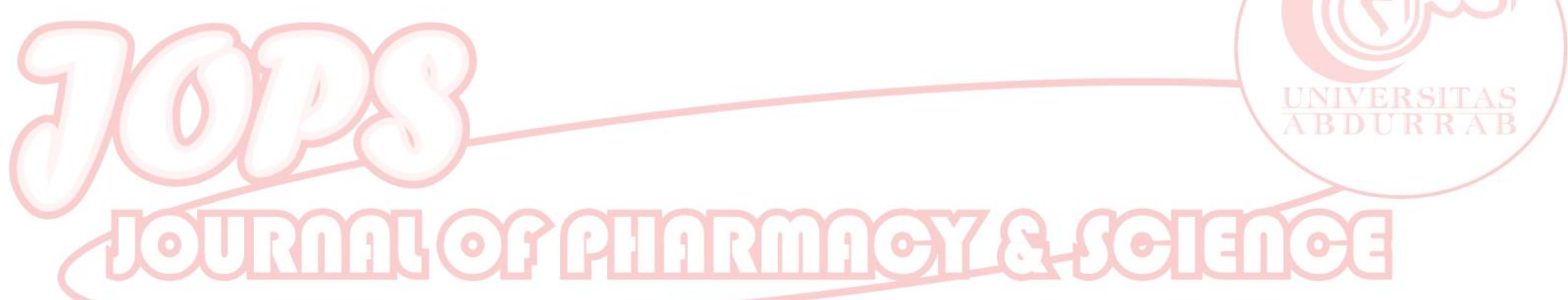

